\title{
Predominant location of coronary artery atherosclerosis in the left anterior descending artery. The impact of septal perforators and the myocardial bridging effect
}

\author{
Jarosław Wasilewski ${ }^{1}$, Jacek Niedziela ${ }^{1}$, Tadeusz Osadnik ${ }^{1}$, Agata Duszańska ${ }^{1}$, Wojciech Sraga², \\ Piotr Desperak ${ }^{1}$, Jolanta Myga-Porosiło², Zuzanna Jackowska², Andrzej Nowakowski ${ }^{3}$, Jan Głowacki ${ }^{4}$ \\ ${ }^{1}$ Third Department of Cardiology, Medical University of Silesia in Katowice, School of Medicine with Division of Dentistry \\ in Zabrze, Silesian Center for Heart Diseases, Poland \\ ${ }^{2}$ Department of Radiology, Medical University of Silesia in Katowice, School of Medicine with Division of Dentistry in Zabrze, \\ Poland \\ ${ }^{3}$ Department of Mechanical Engineering, University of Sheffield, England \\ ${ }^{4}$ Department of Diagnostic Imaging, Medical University of Silesia, Silesian Center for Heart Diseases in Zabrze, Poland
}

Kardiochirurgia i Torakochirurgia Polska 2015; 12 (4): 379-385

\begin{abstract}
Introduction: Coronary artery atherosclerosis presents characteristic patterns of plaque distribution despite systemic exposure to risk factors. We hypothesized that local hemodynamic forces induced by the systolic compression of intramuscular septal perforators could be involved in atherosclerotic processes in the left anterior descending artery (LAD) adjacent to the septal perforators' origin. Therefore we studied the spatial distribution of atherosclerosis in coronary arteries, especially in relation to the septal perforators' origin.

Material and methods: 64-slice computed tomography angiography was performed in 309 consecutive patients (92 male and 217 female) with a mean age of 59.9 years. Spatial plaque distribution in the LAD was analyzed in relation to the septal perforators' origin. Additionally, plaque distribution throughout the coronary artery tree is discussed.

Results: The coronary calcium score (CCS) was positive in 164 patients (53.1\%). In subjects with a CCS $>0$, calcifications were more frequent in the $\operatorname{LAD}(n=150,91.5 \%)$ compared with the right coronary artery (RCA) $(n=94,57.3 \%)$, circumflex branch (CX) $(n=76,46.3 \%)$ or the left main stem $(n=42,25.6 \%)$ ( $p<0.001)$. Total CCS was higher in the LAD at 46.1 (IQR: 104.2) and RCA at 34.1 (IQR: 90.7) than in the CX at 16.8 (IQR: 61.3) $(p=0.007)$. In patients with calcifications restricted to a single vessel $(n=54)$, the most frequently affected artery was the $\operatorname{LAD}(n=42,77.8 \%)$. In patients with lesions limited to the LAD, the plaque was located mostly $(n=37,88.1 \%)$ adjacent to the septal perforators' origin.

Conclusions: We demonstrated that coronary calcifications are most frequently located in the LAD in proximity to the septal branch origin. A possible explanation for this phenom-
\end{abstract}

\section{Streszczenie}

Wstęp: Miażdżyca tętnic wieńcowych objawia się charakterystycznym wzorem dystrybucji blaszki miażdżycowej pomimo ogólnoustrojowego narażenia na czynniki ryzyka. Autorzy przedstawiają hipotezę, że miejscowe siły hemodynamiczne wywołane przez skurczowy ucisk wewnątrzmięśniowych perforatorów przegrody mogą mieć udział w procesach miażdżycowych w gałęzi międzykomorowej przedniej lewej tętnicy wieńcowej (left anterior descending - LAD) w sąsiedztwie odejścia tętnic przegrodowych.

Materiat i metody: Badanie angiograficzne za pomocą 64-rzędowej tomografii komputerowej przeprowadzono u 309 kolejnych pacjentów (92 mężczyzn i 217 kobiet), średnia wieku 59,9 roku. Przestrzenną dystrybucję blaszki w gałęzi LAD przeanalizowano w odniesieniu do miejsca odejścia gałęzi przegrodowych. Omówiono dystrybucję blaszki w całym układzie tętnic wieńcowych. Wyniki: Dodatni wynik wskaźnika uwapnienia tętnic wieńcowych (coronary calcium score - CCS) odnotowano u 164 (53,1\%) pacjentów. U pacjentów z CCS > 0 zwapnienia były częstsze w gałęzi LAD ( $n=150,91,5 \%)$ w porównaniu z prawą tętnicą wieńcową (RCA) ( $n=94,57,3 \%)$, gałęzią okalającą (CX) $(n=76$, $46,3 \%)$ czy pniem lewej tętnicy wieńcowej ( $n=42,25,6 \%)$. Całkowity CCS był wyższy w gałęziach LAD - 46,1 (IQR: 104,2) i RCA - 34,1 (IQR: 90,7) niż w gałęzi CX - 16,8 (IQR: 61,3). U pacjentów, u których zwapnienie występowało tylko w jednym naczyniu ( $n=54)$, zmieniona patologicznie była najczęściej gałąź LAD $(n=42,77,8 \%)$. U pacjentów ze zmianami ograniczonymi jedynie do LAD blaszka była najczęściej umiejscowiona ( $n=37,88,1 \%)$ w sąsiedztwie odejścia tętnic przegrodowych. Wnioski: Zwapnienia wieńcowe występują najczęściej w gałęzi międzykomorowej przedniej LAD w pobliżu odejścia gałęzi

Address for correspondence: Joanna Myga-Porosiło, MD, Department of Radiology, Medical University of Silesia in Katowice, School of Medicine with Division of Dentistry in Zabrze, 13-15 3 Maja St., 41-800 Zabrze, Poland, phone: +48 502315 750, e-mail: jmyga@interia.pl 
enon could be the dynamic compression of the tunneled septal branches, which may result in disturbed blood flow in the adjacent LAD segment (milking effect).

Key words: atherosclerosis, coronary arteries, computed tomography angiography.

\section{Introduction}

Atherosclerotic processes involve endothelial dysfunction and local infiltration of fatty deposits with a subsequent intimal calcification resembling osteogenesis [1, 2]. Coronary artery calcifications occur almost exclusively in atherosclerotic plaques. Moreover, the amount of calcium correlates with the overall magnitude of atherosclerotic plaque burden [2, 3].

Despite the fact that risk factors are systemic, atherosclerotic plaques develop in a non-random manner. Preferred locations are lateral walls of the bifurcations, areas near to the side branches and branch ostia. Atherosclerotic plaques, particularly at the early stage, are eccentric, and in segments where vessels have no side branches, they emerge from the inner curvature. Plaque distribution in the "risk points" indicates the influence of blood flow conditions on the initiation and development of atherosclerosis [4, 5].

Atherosclerotic plaques are not uniformly distributed throughout the coronary artery tree. Lesions are predominantly located in the left coronary artery [6-9]. Necropsy studies and cardiac computed tomography angiography (CCTA) have demonstrated the highest plaque and calcium deposit burden in the left anterior descending artery (LAD) followed by the right coronary artery (RCA), circumflex branch (CX) and left main stem (LM) [10-15]. The distribution of calcifications tends to cluster within the proximal third of the LAD and CX, except in the RCA, where plaques are more uniformly distributed $[16,17]$.

The purpose of the present study was to demonstrate the spatial distribution of coronary calcifications and plaque locations using a coronary calcium score (CCS) and coronary CCTA evaluation. We hypothesized that the predominant location of coronary atherosclerosis in the proximal LAD may be linked to septal perforators (SP). Septal branches run within the heart muscle; therefore systolic compressions of SP may induce retrograde blood flow in the adjacent LAD segment, especially in patients with left ventricular hypertrophy, which has been demonstrated in patients with hypertrophic cardiomyopathy $[18,19]$. Therefore, similarly to myocardial bridging, septal perforators may be considered a predisposing factor for coronary atherosclerosis at least in patients with left ventricular hypertrophy.

\section{Material and methods \\ Study population}

We prospectively recruited 309 consecutive patients (92 male and 217 female; mean age 59.9 years) who underwent a CCTA and concomitant coronary calcium scoring (64-slice przegrodowej. Wyjaśnieniem tego zjawiska może być dynamiczny ucisk wewnątrzmięśniowych tętnic przegrodowych, który może powodować zaburzenia przepływu w sąsiadującym segmencie gałęzi LAD.

Słowa kluczowe: miażdżyca, tętnice wieńcowe, angiografia tomografii komputerowej.

CT scanner; Siemens Somatom Sensation, Germany) because of a definite or suspected coronary artery disease in our department (Silesian Center for Heart Diseases, Poland) between January and December 2012. Patients with history of a previous percutaneous coronary intervention and/or coronary artery bypass grafting, myocardial bridging or coronary vascular anomalies were excluded from the study. The following cardiac risk factors were recorded in the database: hypertension (history of hypertension or antihypertensive therapy), diabetes mellitus (fasting blood glucose level $>7 \mathrm{mmol} / \mathrm{l}$ or use of oral antidiabetic therapy or insulin), smoking (defined as current smoker or previous smoker within the last year) and a positive family history (presence of CAD in first-degree relatives $<55$ years of age if male and $<65$ years of age if female). Laboratory tests were performed for total cholesterol, fasting glucose, full blood count, C-reactive protein (CRP) and estimated glomerular filtration rate. The study has been approved by the local Ethics Committee.

\section{Coronary artery calcium score analysis}

Coronary calcium score (CCS) was assessed by a noncontrast CT scan with a $3.0 \mathrm{~mm}$ slice using the following acquisition: $24 \times 1.2 \mathrm{~mm}$, gantry rotation time of $330 \mathrm{~ms}$, pitch of 0.2, maximum effective tube current of $190 \mathrm{mAs}$, tube voltage of $120 \mathrm{kV}$ with an automated dose modulation. Calcified foci were defined as regions of opacification with a density of $>130$ Hounsfield units and an area of $\geq 3$ contiguous pixels $\left(1.0 \mathrm{~mm}^{2}\right)$ based on the scoring algorithm of Agatston et al. [20]. The images for the CCS were analyzed with a commercially available software package (Siemens Calcium Score, Siemens, Germany). The number of calcium deposits and total coronary calcium score were separately evaluated in the LAD, CX branches, LM and RCA. Calcifications located in the intermediate artery were classified as CX lesions.

\section{Cardiac computed tomography angiography imaging protocol}

In patients with heart rate $>60$ beats/min, metoprolol $(2.5 \mathrm{mg}$ to $10 \mathrm{mg}$ ) was administered intravenously to reduce the heart rate. For coronary vasodilatation, all patients with systolic blood pressure $\geq 110 \mathrm{mmHg}$ received nitroglycerin sublingually. Contrast timing was tested using an initial bolus-timing scan with an acquisition of $64 \mathrm{~mm} \times 0.6 \mathrm{~mm}$, gantry rotation time of $330 \mathrm{~ms}$, pitch of 0.2 , slices of $0.6 \mathrm{~mm}$, tube voltage of $120 \mathrm{kV}$ and maximum effective tube current of $900 \mathrm{mAs}$. An electrocardiography-gated tube current modulation was used 
in patients with stable sinus rhythm to reduce radiation exposure. In the whole studied group CCTA data were recorded using an offline workstation (Leonardo, Siemens, Germany). Images were reconstructed in mid-diastole with an individually optimized position of the reconstruction window. Plaques were identified as obstructive if diameter stenosis was $50 \%$ or greater. Coronary artery segments were classified according to the 15-segment AHA classification [21].

\section{Statistics}

A Shapiro-Wilk goodness-of-fit test was used for normality testing. The results are shown as mean \pm SD or median with (interquartile range - IQR). Group comparisons were tested by the unpaired Student's $t$-test and the oneway ANOVA for continuous variables and the Mann-Whitney or the Kruskal-Wallis test for non-parametric testing. Qualitative variables are expressed as number of patients $(n)$ and percentage (\%) and were compared using the $\chi^{2}$ test. $P$ values $<0.05$ were considered statistically significant. All calculations were performed using the commercially available statistical package Statistica 10 (StatSoft Inc., Tulsa, Oklahoma).

\section{Results}

The CCS computed by the Agatston method was positive in 164 patients (53.1\%). Patients with a positive CCS were older than subjects with a CCS $=0$ (64 years [IQR 13] vs. 57 years [IQR 11]; $p<0.001)$. Hypertension was more common in patients with a CCS $>0$ (77\% vs. $41 \%$; $p<0.001)$ There was a significant difference in fasting blood glucose, diabetes prevalence and CRP concentrations, but there was no difference in total cholesterol and its fractions (Table I).

Among the subjects with a CCS $>0$, the predominant location of calcifications was the LAD (91.5\%), followed by the RCA (57.3\%), CX (46.3\%) and LM stem (25.6\%) $(p<0.001)$. The number of coronary calcified deposits followed the same pattern (397 vs. 226 vs. 157 vs. 49; $p<0.001$ ). Total CCS was higher in the LAD at 46.1 (IQR: 104.2) and RCA at 34.1 (IQR: 90.7) compared to the CX at 16.8 (IQR: 61.3) $(p=0.007)$. In patients with a single vessel calcification $(n=54)$, the most frequently affected artery was the $\operatorname{LAD}(n=42,77.8 \%)$ (Table II). Obstructive plaques were also more common in the LAD. In patients with calcifications limited to the LAD only, plaques were located in segments 6 and/or 7 adjacent to the septal perforators' origin in 37 subjects (88.1\%) (Fig. 1, panels A and B).

Tab. I. Baseline characteristics

\begin{tabular}{|c|c|c|c|c|}
\hline & Whole population, $n=309$ & $\mathrm{CS}=0, n=145$ & $\mathrm{CS}>0, n=164$ & $p$ \\
\hline Sex - female, $n / \%$ & $217 / 70$ & $116 / 80$ & $101 / 62$ & $0.005^{*}$ \\
\hline Age (years) & $60(13)$ & $57(11)$ & $64(13)$ & $<0.001^{\dagger}$ \\
\hline $\mathrm{BMI}\left(\mathrm{kg} / \mathrm{m}^{2}\right)$ & $27.7(6.6)$ & $27.3(7.7)$ & $28.1(6.4)$ & $0.26^{\dagger}$ \\
\hline Waist (cm) & $91 \pm 13$ & $89 \pm 12$ & $93 \pm 13$ & $0.07^{\ddagger}$ \\
\hline $\mathrm{Hip}(\mathrm{cm})$ & $105 \pm 10$ & $105 \pm 9$ & $106 \pm 11$ & $0.7^{\ddagger}$ \\
\hline Heart rate $(1 / \mathrm{min})$ & $67 \pm 9$ & $67 \pm 7$ & $67 \pm 10$ & $0.9^{\ddagger}$ \\
\hline $\mathrm{SBP}(\mathrm{mmHg})$ & $142 \pm 18$ & $139 \pm 18$ & $146 \pm 18$ & $0.09^{\ddagger}$ \\
\hline $\mathrm{DBP}(\mathrm{mmHg})$ & $84 \pm 9$ & $84 \pm 10$ & $84 \pm 9$ & $0.9^{\ddagger}$ \\
\hline Hypertension (\%) & 60 & 41 & 77 & $<0.001^{*}$ \\
\hline Diabetes type 2 (\%) & 13 & 6 & 19 & $0.005^{*}$ \\
\hline Smoking (\%) & 19 & 18 & 19 & $0.86^{*}$ \\
\hline Family history (\%) & 52 & 53 & 52 & $0.89^{*}$ \\
\hline $\mathrm{Hb}(\mathrm{mmol} / \mathrm{l})$ & $8.6 \pm 0.7$ & $8.6 \pm 0.7$ & $8.6 \pm 0.7$ & $0.8^{\ddagger}$ \\
\hline $\mathrm{PLT}\left(\times 10^{3} / \mathrm{mm}^{3}\right)$ & $217(76)$ & $233(80)$ & $205(68)$ & $0.3^{\dagger}$ \\
\hline Fasting glucose (mmol/l) & $5.4(1.0)$ & $5.3(0.8)$ & $5.7(1.2)$ & $0.008^{\dagger}$ \\
\hline Total cholesterol $(\mathrm{mmol} / \mathrm{l})$ & $5.3 \pm 1.1$ & $5.4 \pm 1.1$ & $5.1 \pm 1.1$ & $0.3^{\ddagger}$ \\
\hline $\mathrm{LDL}(\mathrm{mmol} / \mathrm{l})$ & $3.1 \pm 1.0$ & $3.1 \pm 1.0$ & $3.1 \pm 1.1$ & $0.7^{\ddagger}$ \\
\hline $\mathrm{HDL}(\mathrm{mmol} / \mathrm{l})$ & $1.5 \pm 0.4$ & $1.5 \pm 0.3$ & $1.5 \pm 0.4$ & $0.6^{\ddagger}$ \\
\hline Triglycerides $(\mathrm{mmol} / \mathrm{l})$ & $1.4 \pm 0.7$ & $1.5 \pm 0.8$ & $1.3 \pm 0.5$ & $0.1^{\ddagger}$ \\
\hline $\mathrm{CRP}(\mathrm{mg} / \mathrm{dl})$ & $1.3(1.7)$ & $0.9(1.4)$ & $1.6(1.7)$ & $0.025^{\dagger}$ \\
\hline $\mathrm{eGFR}\left(\mathrm{ml} / \mathrm{min} \times 1.73 \mathrm{~m}^{2}\right)$ & $95(32)$ & $95(39)$ & $93(30)$ & $0.6^{\dagger}$ \\
\hline
\end{tabular}

${ }^{*}-\chi^{2}$ test, $^{\dagger}-$ Mann-Whitney test, ${ }^{\ddagger}-$ Student's $t$-test

$\mathrm{BMI}$ - body mass index, SBP - systolic blood pressure, DBP - diastolic blood pressure, PLT - platelet count, CRP - C-reactive protein, eGFR - estimated glomerular filtration rate (Cockcroft-Gault), LDL - low-density lipoprotein, HDL - high-density lipoprotein 
Tab. II. Comparison of calcium deposition and plaque distribution in coronary artery segments in 164 patients with coronary calcium score $>0$

\begin{tabular}{lccccc} 
& LAD, $n=150$ & RCA, $n=94$ & CX, $n=76$ & LM, $n=42$ & $p$ \\
Number of calcium deposits $(n)$ & 397 & 226 & 157 & 49 & $<0.001^{\dagger}$ \\
\hline Total calcium score (median $[\mathrm{IQR}])$ & $46.1(104.2)$ & $34.1(90.7)$ & $16.8(61.3)$ & $35.1(77.2)$ & $0.007^{\star}$ \\
\hline Localization of calcium calcifications (\%) & 91.5 & 57.3 & 46.3 & 25.6 & $<0.001^{\dagger}$ \\
\hline Stenosis $>50 \%(n / \%)$ & $37 / 24.6$ & $14 / 14.9$ & $7 / 9.2$ & $3 / 7.1$ & $<0.001^{\dagger}$ \\
\hline Patients $(n=54)$ with single vessel calcifications $(n / \%)$ & $42 / 77.8$ & $4 / 7.4$ & $5 / 9.3$ & $3 / 5.6$ & $<0.001^{\dagger}$ \\
\hline${ }^{*}-$ Kruskal-Wallis test, ${ }^{\dagger}-\chi^{2}$ test & & & &
\end{tabular}

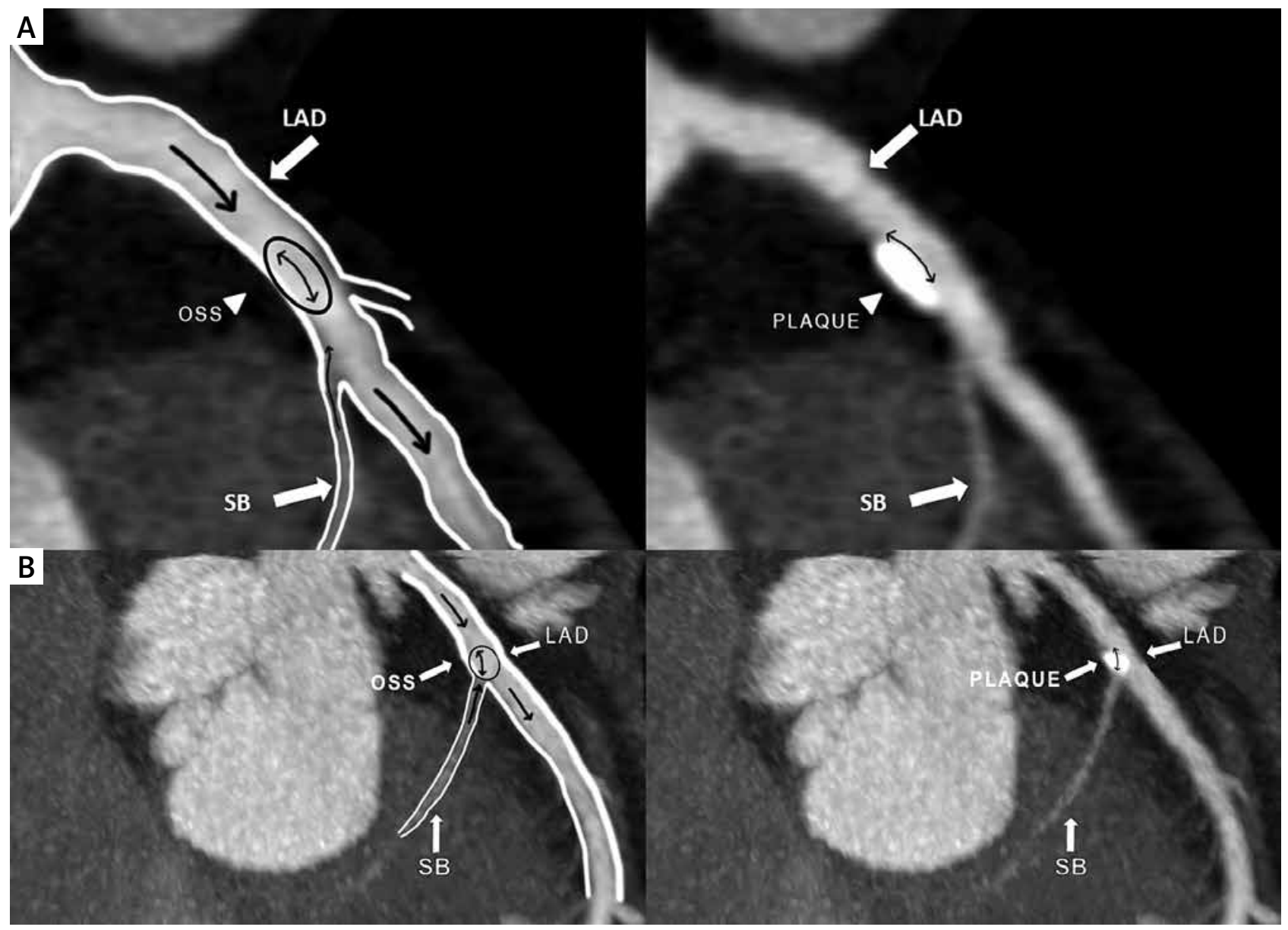

Fig. 1. Panel A and B. Multiplanar reconstructed images of the left anterior descending artery (LAD) and the septal branch. Diagram illustrating plaque location in the proximal segment of the LAD artery. Note the anatomy of the septal branch and its intramyocardial course. In proximity to the septal branch ostium, the LAD endothelial cells are exposed to atherogenic low oscillatory shear stress, which leads to plaque formation (left panel). On the right, the corresponding region of the plaque location (myocardial bridging effect) $L A D$ - left anterior descending artery, OSS - oscillatory shear stress, SB - septal branch

\section{Discussion}

\section{Plaque distribution patterns in the coronary artery tree}

According to a retrospective analysis of the largest coronary angiographic database, in $34.7 \%$ of a total of 13,305 patients plaques were observed only in the left coronary artery compared with $6.5 \%$ exclusively in the right coronary artery [9]. Necropsy and CCTA studies revealed that the highest average amounts of atherosclerosis and calci- fied lesions accumulate in the proximal segments of the LAD, followed by the RCA, CX and LM stem [6, 10, 11]. Our results are in agreement with previous findings from necropsy protocols and angiographic studies. They confirm the predominance of atherosclerosis in the LAD artery over the RCA, CX and LM stem [5-9, 17] (Table II). Enrico et al. demonstrated in a group of 73 patients with a total of 282 plaques detected by CCTA that $46.3 \%$ of the atherosclerotic lesions were located in the LAD, 25.9\% in the RCA, $18.3 \%$ in the CX and $8.1 \%$ in the LM [14]. The same pattern of high- 

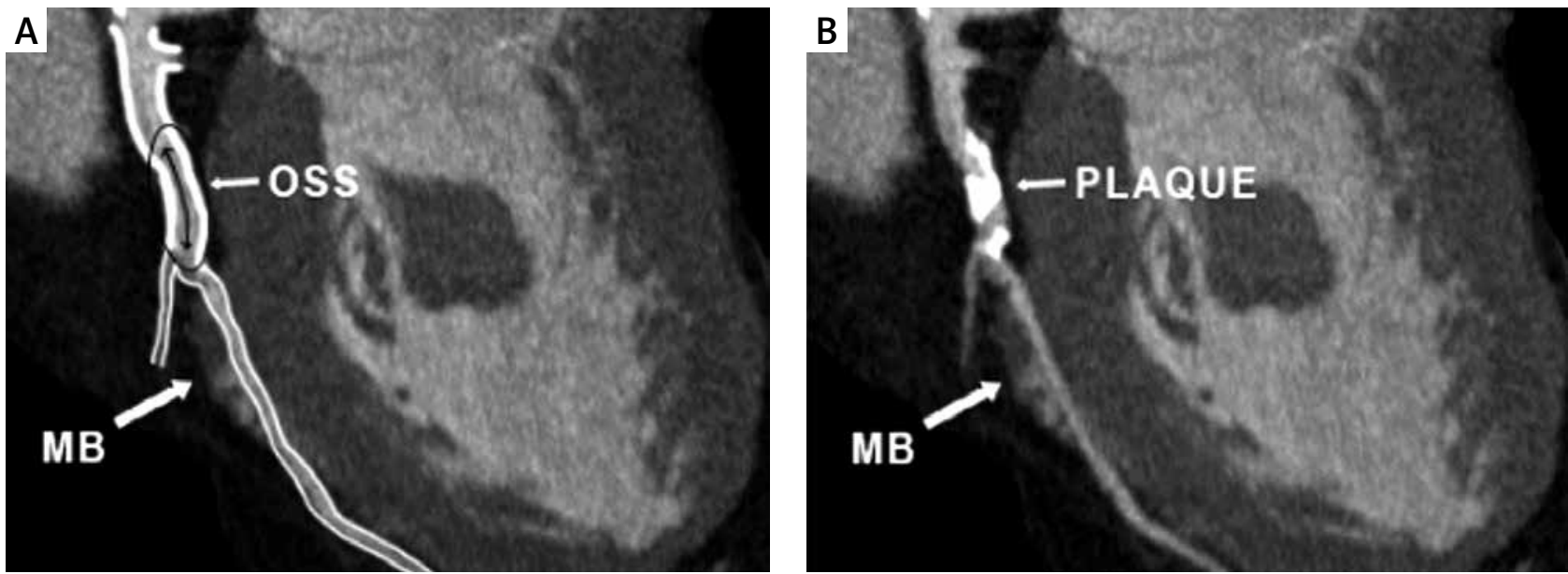

Fig. 2. Multiplanar reconstructed image of the left anterior descending artery (LAD). Diagram illustrating plaque location in the LAD in patient with myocardial bridge. At the segment adjacent to the myocardial bridge, retrograde coronary blood flow occurs at the systole and the endothelial cells are exposed to atherogenic low oscillatory shear stress (left panel). On the right, the corresponding region of the plaque location (myocardial bridging effect). The intramyocardial segment of the coronary artery is free of plaques $L A D$ - left anterior descending artery, OSS - oscillatory shear stress, MB - myocardial bridge

est CCS in the LAD and lower CCS in the RCA, CX and LM stem was reported by Erciyes et al. [15]. Saur et al. [22] and Ehara et al. [17] demonstrated a non-uniform distribution of plaques not only throughout the coronary vasculature but also along segments of the same vessel, with a predominance of atherosclerosis in the proximal LAD. Our results extend previous observations, and we revealed that coronary plaques are most frequently located not only in the LAD but also in proximity to the septal branch origin.

\section{Wall shear stress and atherosclerosis}

Blood vessels are constantly subjected to various types of hemodynamic forces, including wall shear stress (WSS) induced by blood flow. Wall shear stress is the tangential drag force of circulating blood onto the endothelial surface of the artery. The pathophysiology of the wall shear stress and its role in the genesis of atherosclerosis have been extensively studied [23]. It is hypothesized that the accumulation of atheromatous material in the artery "risk points" is the result of prolonged residence time of circulating proatherogenic particles in the disturbed flow field. Prolonged residence time may promote mass transport into the vessel wall, especially in cases of increased wall permeability due to an abnormal WSS. Additionally, it is well established that the initiation and development of atherosclerosis are also attributed to complex mechanotransduction pathways regulated by WSS, including the activation of numerous proatherogenic genes and up-regulation of pro-inflammatory mediators that are engaged in osteogenic signaling and differentiation of vascular cells [24, 25].

\section{Myocardial bridging and atherosclerosis}

Myocardial bridging (MB) is a congenital abnormality and most often involves the LAD. The intramural and distal segments of the bridged vessels remain free from atherosclerosis, contrary to the proximal segments, which are more susceptible to the development of atherosclerotic lesions (Fig. 2) [26, 27]. Retrograde blood flow observed in a segment proximal to $M B$ is the result of intramural vessel compression during systole. It may lead to time-varying bidirectional flow formations generating atherogenic low oscillatory WSS [26-29]. Advanced atherosclerosis in the segment proximal to MB occurs when a myocardial bridge is longer and thicker which may affect the hemodynamics of the blood flow during systolic vessel compressions [26, 30-32]. Non-tortuous, non-branching arteries are exposed to uniform unidirectional flow and are exposed to a relatively high WSS. Thus, wall shear stress within a normal range is atheroprotective, which may explain the absence of atherosclerosis in the bridged coronary artery segments and septal perforators. However, plaques can occasionally be found in the septal branch ostium before its entry to the myocardium [33-35].

\section{The anatomy of the septal perforating arteries}

The interventricular septum is the most densely vascularized part of the heart. It receives two-thirds of its blood supply from penetrating septal branches originating from the proximal part of the LAD. The remaining one-third of the inferior portion of the septum is irrigated by relatively short septal branches from the posterior descending artery [36-38]. Infrequently, septal perforators arise from the diagonal branch, RCA or LM [39-42]. The first septal perforator is usually the largest [43]. The length of the septal perforators ranges from 40 to $80 \mathrm{~mm}$ and tends to become shorter as they reach the apex [44]. Generally, intramuscular septal branches are resistant to atherosclerosis [33, 34]. Ultrasound studies evaluating plaque distribution in the LAD have shown that in the LAD segments adjacent to the first septal perforator, mean atheroma area and mean intimal thickness were substantially greater on the septal than the antiseptal side [45]. 


\section{Left ventricular hypertrophy}

Left ventricular hypertrophy is an important risk factor for subclinical atherosclerosis and calcifications [46]. In a study of 2,724 young adult subjects positive for coronary artery calcium, left ventricular mass and wall thickness were associated with an increased CCS [47]. On the other hand, absence of left ventricular hypertrophy was a prerequisite for a CCS of zero [48]. According to Erciyes et al., CCS of the LAD has been found to be higher in hypertensive patients compared with normotensive subjects [15]. Abnormal patterns of coronary flow velocity and flow reversal in the LAD have been observed in patients with left ventricular hypertrophy in conditions such as aortic stenosis and systemic hypertension [49]. Using a Doppler catheter to assess flow pattern, Akasaka et al. noticed a flow reversal in the LAD in subjects with asymmetric left ventricular hypertrophy [18]. Transthoracic color flow and pulsed Doppler echocardiography revealed that abnormal flow in the LAD simply reflected the systolic flow reversal in a septal perforator in the hypertrophied muscle [19].

\section{Conclusions}

The data from our study demonstrate non-uniform calcium deposits and plaque distribution in the coronary tree. The most common location for plaques is the proximal $L A D$, followed by the RCA, CX and LM. Bearing in mind that a hemodynamic milieu could be involved in the genesis of atherosclerosis, we conclude that the proximal LAD segment susceptibility to atherosclerosis can be attributed to the milking effect of septal perforators. In our opinion, systolic compression of the septal intramural branch segment can lead to disturbed flow in the adjacent LAD segment at the side of the septal origin [50]. To confirm our findings, further research, including blood flow simulation by computed fluid dynamics analysis and in vitro ultrasound measurements, is warranted to visualize the flow pattern in the LAD segment adjacent to the septal perforator.

\section{Disclosure}

Authors report no conflict of interests.

\section{References}

1. Hays AG, Kelle S, Hirsch GA, Soleimanifard S, Yu J, Agarwal HK, Gerstenblith G, Schär M, Stuber M, Weiss RG. Regional coronary enothelial function is closely related to local early coronary atherosclerosis in patients with mild coronary artery disease: pilot study. Circ Cardiovasc Imaging 2012; 5: 341-348.

2. Demer LL, Watson KE, Boström K. Mechanism of calcification in atherosclerosis. Trends Cardiovasc Med 1994; 4: 45-49.

3. Burke AP, Virmani R, Galis Z, Haudenschild CC, Muller JE. 34th Bethesda Conference: Task force \#2 - What is the pathologic basis for new atherosclerosis imaging techniques? J Am Coll Cardiol 2003; 41: 1874-1886.

4. Markl M, WegentF, Zech T, Bauer S, Strecker C, Schumacher M, Weiller C, Hennig J, Harloff A. In vivo wall shear stressdistribution in the carotid artery: effect of bifurcation geometry, internal carotid artery stenosis, and recanalization therapy. Circ Cardiovasc Imaging 2010; 3: 647-655.

5. Davies PF, Shi C, Depaola N, Helmke BP, Polacek DC. Hemodynamics and the focal origin ofatherosclerosis: a spatial approach to endothelial structure, gene expression, and function. Ann N Y Acad Sci 2001; 947: 7-16.
6. Eggen DA, Strong JP, McGill HC Jr. Coronary calcification. Relationship to clinically significant coronary lesions and race, sex, and topographic distribution. Circulation 1965; 32: 948-955.

7. Montenegro MR, Eggen DA. Topography of atherosclerosis in the coronary arteries. Lab Invest 1968; 18: 586-593.

8. Schmermund A, Baumgart D, Möhlenkamp S, Kriener P, Pump H, Grönemeyer D, Seibel R, Erbel R. Natural history and topographic pattern of progression of coronary calcification in symptomatic patients: an electronbeam CT study. Arterioscler Thromb Vasc Biol 2001; 21: 421-426.

9. Giannoglou GD, Antoniadis AP, Chatzizisis YS, Louridas GE. Difference in the topography of atherosclerosis in the left versus right coronary artery in patients referred for coronary angiography. BMC Cardiovasc Disord 2010; 10: 26.

10. Iwasaki K, Matsumoto T, Aono H, Furukawa H, Nagamachi K, Samukawa M. Distribution of coronary atherosclerosis in patients with coronary artery disease. Heart Vessels 2010; 25: 14-18.

11. Ackerman RF, Dry TJ, Edwards JE. Relationship of various factors to the degree of coronary atherosclerosis in women. Circulation 1950; 1: 1345-1354.

12. Lee S, Choi EK, Chang HJ, Kim CH, Seo WW, Park JJ, Sang II, Chun EJ, Chang SA, Kim HK, Kim YJ, Koo BK, Choi DJ, Oh B. Subclinical coronary artery disease as detected by coronary computed tomography angiography in an asymptomatic population. Korean Circ J 2010; 40: 434-441.

13. Lai HM, Holtzman D, Aronow WS, DeLuca AJ, Ahn C, Matayev S, Belkin RN. Association of coronary artery calcium with severity of myocardial ischemia in left anterior descending, left circumflex, and right coronaryartery territories. Clin Cardiol 2012; 35: 61-63.

14. Enrico B, Suranyi P, Thilo C, Bonomo L, Costello P, Schoepf UJ. Coronary artery plaque formation at coronary $\mathrm{CT}$ angiography: morphological analysis and relationship to hemodynamics. Eur Radiol 2009; 19: 837-844.

15. Erciyes D, Şener M, Duran C, Şirvanc M, Demiroglu C, Gülbaran M. Segmental distribution of calcium scores in the coronary arteries. Türk Kardiyol Dern Arş - Arch Turk Soc Cardiol 2012; 40: 671-680.

16. Golinvaux N, Maehara A, Mintz GS, Lansky AJ, McPherson J, Farhat N, Marso S, de Bruyne B, Serruys PW, Templin B, Cheong WF, Aaskar R, Fahy M, Mehran R, Leon M, Stone GW. An intravascular ultrasound appraisal of atherosclerotic plaque distribution in diseased coronary arteries. Am Heart J 2012; 163: 624-631.

17. Ehara S, Matsumoto K, Hasegawa T, Otsuka K, Sakaguchi M, Shimada K, Yoshikawa J, Yoshiyama M. Characteristic patterns of the longitudinal and circumferential distribution of calcium deposits by parent coronary arteries observed from computed tomography angiography. Heart Vessels 2015 [Epub ahead of print].

18. Akasaka T, Yoshikawa J, Yoshida K, Maeda K, Takagi T, Miyake S. Phasic coronary flow characteristics in patients with hypertrophic cardiomyopathy: a study by coronary Doppler catheter. J Am Soc Echocardiogr 1994; 7: 9-19.

19. Watanabe N, Akasaka T, Yamaura Y, Akiyama M, Kaji S, Saito Y, Yoshida K. Intramyocardial coronary flow characteristics in patients with hypertrophic cardiomyopathy: non-invasive assessment by transthoracic Doppler echocardiography. Heart 2003; 89: 657-658.

20. Agatston AS, Janowitz WR, Hildner FJ, Zusmer NR, Viamonte M Jr, Detrano R. Quantification of coronary artery calcium using ultrafast computed tomography. J Am Coll Cardiol 1990; 15: 827-832.

21. Austen WG, Edwards JE, Frye RL, Gensini GG, Gott VL, Griffith LS, McGoon DC, Murphy ML, Roe BB. A reporting system on patients evaluated for coronary artery disease. Report of the Ad Hoc Committee for grading of coronary artery disease, Council of Cardiovascular Surgery, American Heart Association. Circulation 1975; 51: 35-40.

22. Saur SC, Cattin PC, Desbiolles L, Fuchs TJ, Székely G, Alkadhi H. Prediction rules for the detection of coronary artery plaques: evidence from cardiac CT. Invest Radiol 2009; 44: 483-490.

23. Cunningham KS, Gotlieb Al. The role of shear stressin the pathogenesis of atherosclerosis. Lab Invest 2005; 85: 9-23.

24. Phinikaridou A, Hua N, Pham T, Hamilton JA. Regions of low endothelial shear stress colocalize with positive vascular remodeling and atherosclerotic plaque disruption: an in vivo magnetic resonance imaging study. Circ Cardiovasc Imaging 2013; 6: 302-310.

25. Wasilewski J, Kiljański T, Miszalski-Jamka K. Role of shear stress and endothelial mechanotransduction in atherogenesis. Kardiol Pol 2011; 69: 717-720.

26. Ishikawa Y, Akasaka Y, Ito K, Akishima Y, Kimura M, Kiguchi H, Fujimoto A, Ishii T. Significance of anatomical properties of myocardial bridge on atherosclerosis evolution in the left the anterior descending coronary artery. Atherosclerosis 2006; 186: 380-389. 
27. Ishii T, Asuwa N, Masuda S, Ishikawa Y. The effects of a myocardial bridge on coronary atherosclerosis and ischaemia. J Pathol 1998; 185: 4-9.

28. Ishikawa Y, Akasaka Y, Akishima-Fukasawa Y, luchi A, Suzuki K, Uno M, Abe E, Yang Y, Li CP, Mukai K, Niino H, Tanaka M, Kawahara Y, Sugiura H, Shinagawa T, Morinaga S, Ogata K, Onuma J, Yanagida-lida M, Taki K, Komatsu A, Satoh H, Yamada K, Shimokawa R, Shibuya K, Takahashi K, Ishii T. Histopathologic profiles of coronary atherosclerosis by myocardial bridge underlying myocardial infarction. Atherosclerosis 2013; 226: 118-123.

29. Ishii T, Asuwa N, Masuda S, Ishikawa Y, Kiguchi H, Shimada K. Atherosclerosis suppression in the left anterior descending coronary artery by the presence of a myocardial bridge: an ultrastructural study. Mod Pathol 1991; 4: 424-431.

30. Ishikawa Y, Akasaka Y, Suzuki K, Fujiwara M, Ogawa T, Yamazaki K, Niino H, Tanaka M, Ogata K, Morinaga S, Ebihara Y, Kawahara Y, Sugiura H, Takimoto T, Komatsu A, Shinagawa T, Taki K, Satoh H, Yamada K, Yanagida-lida M, Shimokawa R, Shimada K, Nishimura C, Ito K, Ishii T. Anatomic properties of myocardial bridge predisposing to myocardial infarction. Circulation 2009; 120: 376-383.

31. Ishii T, Hosoda Y, Osaka T, Imai T, Shimada H, Takami A, Yamada H. The significance of myocardial bridge upon atherosclerosis in the left anterior descending coronary artery. J Pathol 1986; 148: 2792-2791.

32. Channer KS, Bukis E, Hartnell G, Rees JR. Myocardial bridging of the coronary arteries. Clin Radiol 1989; 40: 355-359.

33. Chatzizisis YS, Giannoglou GD. Myocardial bridges spared from atherosclerosis: overview of the underlying mechanisms. Can J Cardiol 2009; 25: 219 222.

34. Scher AM. Absence of atherosclerosis in human intramyocardial coronary arteries: a neglected phenomenon. Atherosclerosis 2000; 149: 1-3.

35. Cohen ID, Khosla S, Levin TN, Feldman T. Rotational atherectomy for left anterior descending artery septal perforator stenosis. Catheter Cardiovasc Interv 1999; 46: 79-82.

36. Bertho E, Gagnaon G. A comparative study in three dimension of the bood supply of the normal interventricular septum in human, canine, bovine, ovine and equine heart. Dis Chest 1964; 46: 2512-2562.

37. Farrer-Brown G, Rowles PM. Vascular supply of interventricular septum of human heart. Br Heart J 1969; 31: 727-734.

38. James TN, Burch GE. Blood supply of the human interventricular septum. Circulation 1958; 17: 391-396.

39. Bream PR, Jones JM, Elliott LP. The anomalous septal perforating artery. Its origin from the first diagonal, first marginal, or circumflex artery. Radiology 1981; 138: 301-307.
40. Bream PR, Souza AS Jr, Elliott LP, Soto B, Curry GC. Right superior septa perforator artery: its angiographic description and clinical significance. Am J Roentgenol 1979; 133: 67-73.

41. von Lüdinghausen $M$, Ohmachi N. Right superior septal artery with "normal" right coronary and ectopic "early" aortic origin: a contribution to the vascular supply of the interventricular septum of the human heart. Clin Anat 2001; 14: 312-319.

42. Takeguchi T, Ibukuro K, Fukuda H, Tobe K, Abe S. Anatomy of right superior septal artery demonstrated on the coronary CT scan. Acta Radiol 2012; 53: 23-27.

43. Possatti LL, Ramos HF, Rodrigues H, Musso F. Anatomical study of the anterior intraventricular septal branches and their relationschip with the blood supply of the septomarginal trabercula. Braz J Morphol Sci 2005; 22: 169-174.

44. James TN, Burch GE. Blood supply of the human interventricular septum. Circulation 1958; 17: 391-396.

45. Balghith MA, Schoenhagen P, Foody JM, lyisoy A, Crowe TD, Tuzcu EM, Nissen SE. Atherosclerotic plaque distribution in the left anterior descending coronary artery as assessed by intravascular ultrasound. Am J Cardiol 2003; 91: 443-445.

46. Altunkan S, Erdogan N, Altin L, Budoff MJ. Relation of coronary artery calcium to left ventricular mass and geometry in patients with essential hy pertension. Blood Press Monit 2003; 8: 9-15.

47. Gardin JM, Iribarren C, Detrano RC, Liu K, Schreiner PJ, Loria CM, Wong ND. Relation of echocardiographic left ventricular mass, geometry and wall stress, and left atrial dimension to coronary calcium in young adults (the CARDIA study). Am J Cardiol 2005; 95: 626-629.

48. Ehara S, Shirai N, Okuyama T, Matsumoto K, Matsumura Y, Yoshiyama M. Absence of left ventricular concentric hypertrophy: a prerequisite for zero coronary calcium score. Heart Vessels 2011; 26: 487-494.

49. Yoshikawa J, Akasaka T, Yoshida K, Takagi T. Systolic coronary flow reversal and abnormal diastolic flow patterns in patients with aortic stenosis: assessment with an intracoronary Doppler catheter. J Am Soc Echocardiogr 1993; 6: 516-524

50. Wasilewski J, Roleder M, Niedziela J, Nowakowski A, Osadnik T, Głowacki J, Kryspin M, Poloński L. The Role of septal perforators and "myocardial bridging effect" in atherosclerotic plaque distribution in the coronary artery disease. Pol J Radiol 2015; 80: 195-201. 